CREATIVE WORKS

\title{
Anatomists' work song
}

If not in death

where would we live?

Wrap the night slowly

draw the borders tighter

round our cadaverous caverns.

Woe to the scholar

with insufficient vanity.

and so to work

torn

between scalpel and slab

Call me cartographer;

sternum quill stenographer

Implements of rumination

ruin read for oracles

a geography of fellows.

I am conquistador of corpses

chevalier de la chair inconnue

tanned, salted and ripe for plunder

chaste from forest to glade

navigated, irrigated, in ruin remade.

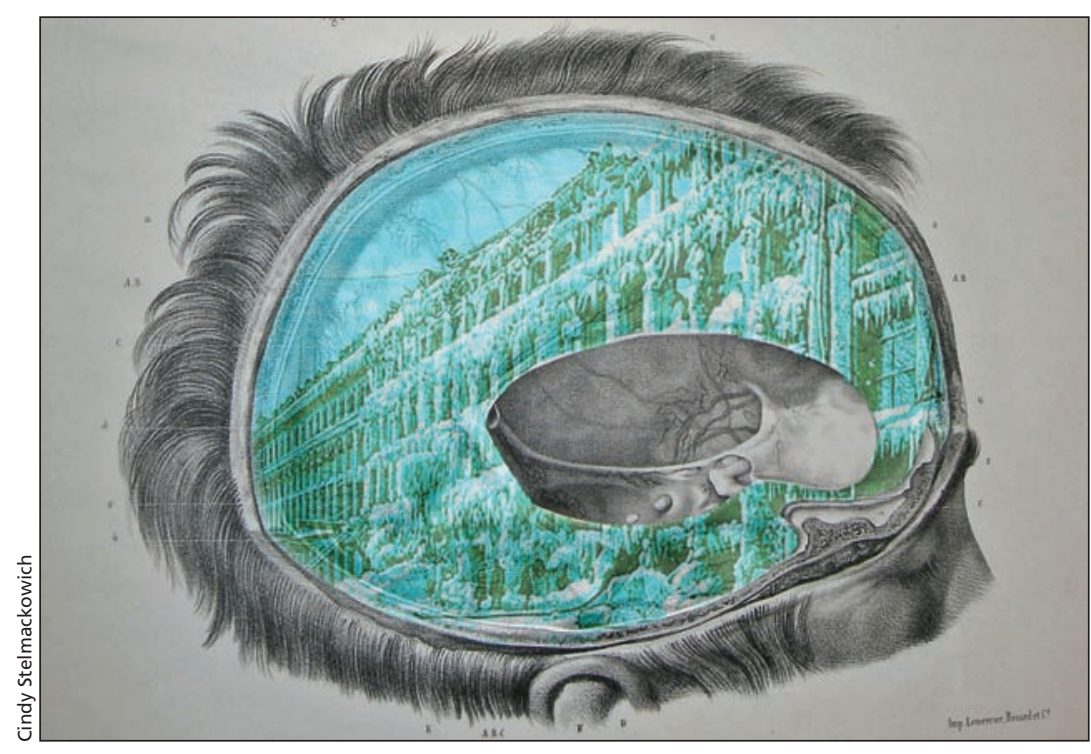

Cindy Stelmackowich, Burning of the Market-House at Kingston, Canada West July 4, 1865 (2008) (detail). Ultrachromium print. $36 \times 51 \mathrm{~cm}$.

If not for breath

what could we give?

Mind the cavity, cool the spade.

Ponderous plumb, hook and gravity

bind the finding fingers of

the hand that made the hand that made.

The rational apparatus

the sick proficient sanity,

the gift of cold calamity.

Call me animator;

call them marionette.

Split and sorted

for posterity, for cybernetic sport.

Reboot this dismantled frame and drift into wakefulness

full into life.

Whisper in your sleep, my specimen.

Beg for the knife.

If not with memory

why fill these cells?

Spill into the spelunking shell,

reliquary of delight and shrinking tales to tell

how she rose, how she fell.

Shrieks, peaks,

for rattles, battles and for death knells.

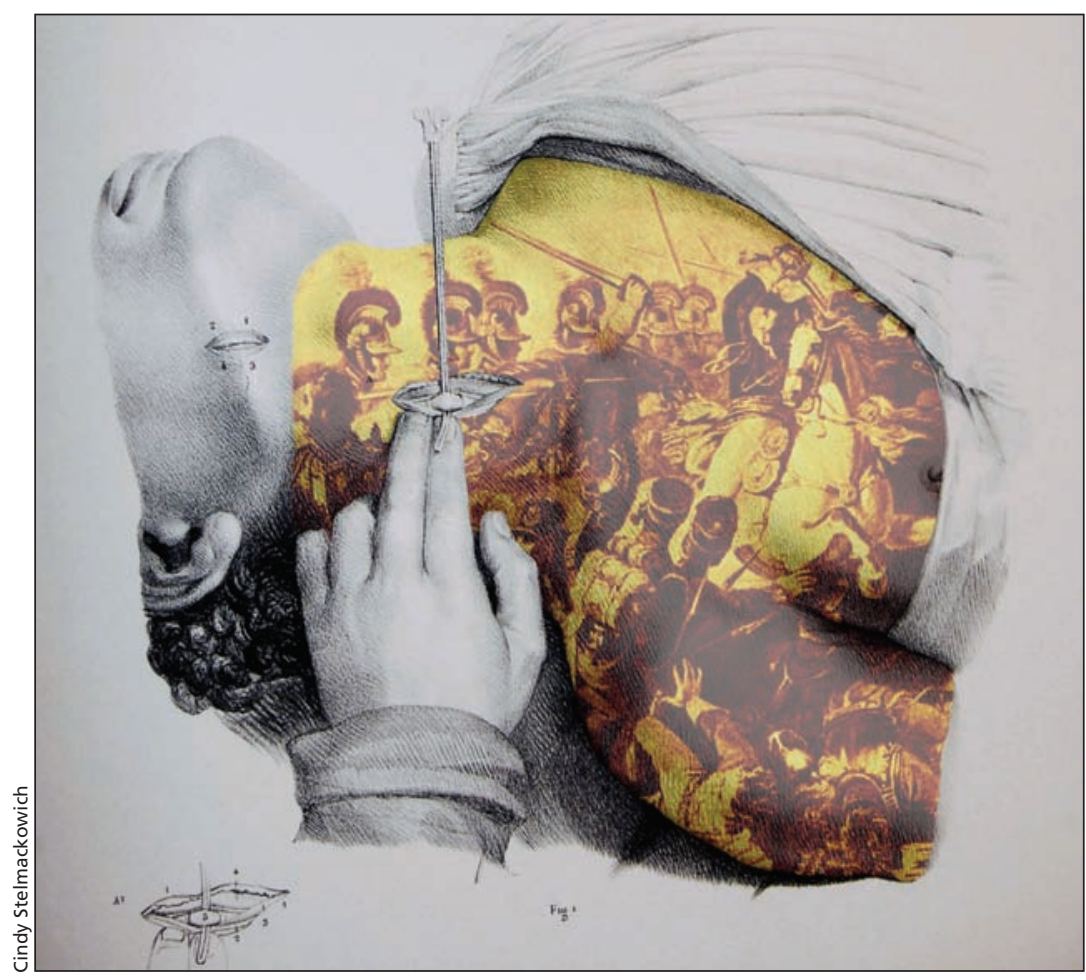

Cindy Stelmackowich, A Frozen Fire in Montreal - c. 1800s (2008) (detail). Ultrachromium print. $36 \times 51 \mathrm{~cm}$. 


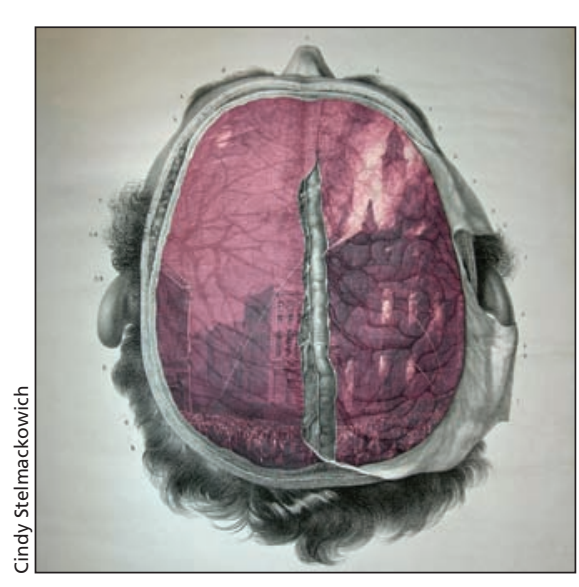

Cindy Stelmackowich, The Last Charge of Napoleon's Old Guard at the Battle of Waterloo, Belgium - June 18, 1815 (2008) (detail). Ultrachromium print. $36 \times$ $51 \mathrm{~cm}$.

Call me pornographer clasping fast to phantasm eros engaging ectoplasm lurid lens unfettered by membrane or morality. My mission subcutaneous dare not to undermine science my wholesome desire stroking toward scattered shrapnel of the sublime shivering glimpse even of the divine

I see vehicles

of demise

still life in profusion

I draw everything

but breath

and thus conclusion.

\section{Kevin Matthews \\ Poet \\ Cindy Stelmackowich PhD \\ Artist}

Ottawa, Ont.

These images are from Anatomy: In Ruins and Remade, an exhibition at the Patrick Mikhail Gallery in Ottawa, Ont., Feb. 4Mar. 4, 2009. Ms. Stelmackowich is an artist, curator and teacher whose artwork related to medical science has been exhibited across North America.

Mr. Matthews has performed his poetry in front of audiences around Canada — from hundreds to handfuls, and from symphonic concert halls to correctional facilities.
ESSAY

\section{From plunger to Punkt-roller: a century of weight-loss quackery}

"People trust the quack with their lives who would not trust him with the loan of a sixpence. They seem to believe advertised testimonials as if they were guaranteed by a prominent physician, forgetting that many obscure prints can be got to write any falsehoods and back up any quackery under the sun. These lying testimonials are paraded in papers that ought to know better than to insert them, and the public believe in their statements as if they were scientific truths." ${ }^{\prime \prime}$ - Dr. Nathaniel Edward Yorke-Davies, 1901

$\mathrm{F}$ rom I Love Lucy-style body jigglers, to heated "slenderizing" jeans and tens of thousands of fad diets, weight-loss quackery has dominated this past century's snake-oil $\bar{\varnothing}$ market. While the marketing of hope will always have its victims, with some of these products it is truly difficult to understand the mentality of the buyer. Did people in the late 1800 s really find hand-drawn before-and-after testimonial pictures to be compelling? Was there really a large German market for the turn of the century's Punkt-roller, the suction-cupped rolling pin? Were there armies of jiggling bodies in basements hoping their weight would bounce away?

Sadly, the answer to all of those questions is a resounding "yes"; preying on the vulnerabilities often associated with obesity has shown itself to be a lucrative business.

Unfortunately, it was not only unscrupulous business people preying on the vulnerable, sometimes it was medical doctors. Take for example Dr. Thomas Lawton. In his 1917 book, The Lawton Method of Weight Reduction, he reports, "I have reduced the weight of thousands of other people and can do it for you. Get that firmly in your mind - you are going to be brought to a normal, comfortable and vigorously healthy weight." ${ }_{2}$ What was his method? Believe it or not it involved

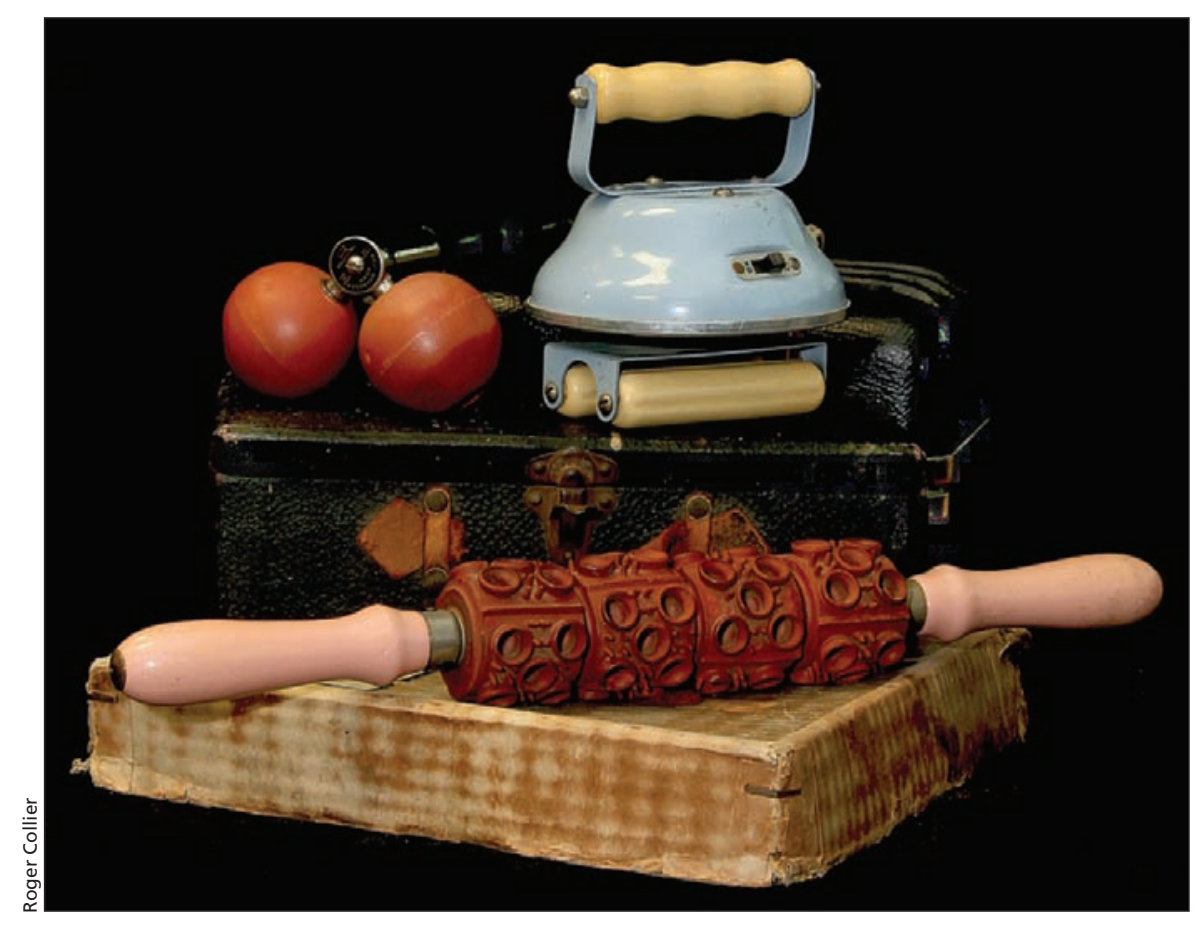

This selection of the author's mechanical "weight-loss" devices includes, in the foreground, the Punkt-roller from Germany, the Knead-Away (left), which was billed by Sears Roebuck as "the scientific way to remove fat," and the "Redusaway" (right), which when plugged in vibrates and ironically blows hot air. 